\title{
Optimizing plant transporter expression in Xenopus oocytes
}

\author{
Huimin Feng ${ }^{1,2}$, Xiudong Xia ${ }^{1}$, Xiaorong Fan ${ }^{1,2^{*}}$, Guohua $\mathrm{Xu}^{1}$ and Anthony J Miller ${ }^{2^{*}}$
}

\begin{abstract}
Background: Rapid improvements in DNA synthesis technology are revolutionizing gene cloning and the characterization of their encoded proteins. Xenopus laevis oocytes are a commonly used heterologous system for the expression and functional characterization of membrane proteins. For many plant proteins, particularly transporters, low levels of expression can limit functional activity in these cells making it difficult to characterize the protein. Improvements in synthetic DNA technology now make it quick, easy and relatively cheap to optimize the codon usage of plant cDNAs for Xenopus. We have tested if this optimization process can improve the functional activity of a two-component plant nitrate transporter assayed in oocytes.

Results: We used the generally available software (http://www.kazusa.or.jp/codon/; http://genomes.urv.es/ OPTIMIZER/) to predict a DNA sequence for the plant gene that is better suited for Xenopus laevis. Rice OsNAR2.1 and OsNRT2.3a DNA optimized sequences were commercially synthesized for Xenopus expression. The template DNA was used to synthesize cRNA using a commercially available kit. Oocytes were injected with cRNA mixture of optimized and original OsNAR2.1 and OsNRT2.3a. Oocytes injected with CRNA obtained from using the optimized DNA template could accumulate significantly more $\mathrm{NO}_{3}{ }^{-}$than the original genes after $16 \mathrm{~h}$ incubation in $0.5 \mathrm{mM}$ $\mathrm{Na}^{15} \mathrm{NO}_{3}$. Two-electrode voltage clamp analysis of the oocytes confirmed that the codon optimized template resulted in significantly larger currents when compared with the original rice cDNA.

Conclusion: The functional activity of a rice high affinity nitrate transporter in oocytes was improved by DNA codon optimization of the genes. This methodology offers the prospect for improved expression and better subsequent functional characterization of plant proteins in the Xenopus oocyte system.
\end{abstract}

Keywords: DNA optimization, Xenopus oocyte, Plant, Nitrate transporter, Uptake, Electrophysiology

\section{Background}

Heterologous expression systems are often used for the functional characterization of a gene. Xenopus laevis oocytes are widely used to express membrane proteins and channels. Over twenty years ago, the first plant membrane proteins were expressed in oocytes and these were a hexose transporter and a $\mathrm{K}^{+}$channel $[1,2]$. Since then, many plant membrane proteins including carriers [3-5], channels [6-9] and aquaporins [10-13] have been successfully expressed in oocytes. Oocyte expression was used to demonstrate function for the first plant nitrate transporter (Chl1, AtNRT1.1

\footnotetext{
* Correspondence: xiaorongfan@njau.edu.cn; tony.miller@jic.ac.uk 'State Key Laboratory of Crop Genetics and Germplasm Enhancement, College of Resources and Environmental Sciences, Nanjing Agricultural University, Nanjing 210095, PR China

${ }^{2}$ Department of Metabolic Biology, John Innes Centre, Norwich Research Park NR4 7UH, UK
}

\section{Biomed Central}

(c) 2013 Feng et al.; licensee BioMed Central Ltd. This is an Open Access article distributed under the terms of the Creative Commons Attribution License (http://creativecommons.org/licenses/by/2.0), which permits unrestricted use, distribution, and reproduction in any medium, provided the original work is properly cited. The Creative Commons Public Domain Dedication waiver (http://creativecommons.org/publicdomain/zero/1.0/) applies to the data made available in this article, unless otherwise stated. or AtNPF6.3) that was identified and later for many more family members [3,14-20]. Some of the plant NRT2 nitrate transporter family members require a second gene NAR2 for function and this requirement was demonstrated using oocyte expression [4,5,21-23]. The high affinity rice nitrate transporter, OsNRT2.3a needs a partner protein, OsNAR2.1 for function in oocytes [22,23].

Although all organisms generally share the same genetic code, each genus has evolved a slightly different pattern of codon usage. Heterologous protein expression in a foreign host may be diminished by factors such as biased codon usage, GC content and repeat sequences. To overcome these limitations, codon optimization can be used to enhance gene expression in various host cells. Heterologous synthetic genes with codon optimization showed increased expression levels in various organisms including $E$. coli $[24,25]$, yeast [26] and mammalian cells $[27,28]$. For many 
plant transporters expressed in Xenopus oocytes, the low levels of expression can often limit the functional assay, making the detailed characterization of the protein difficult. In the past, it was speculated that differing codon bias may explain the very low levels of expression of some plant proteins in oocytes [29]. Improvements in DNA synthesis technology have enabled the technique to be used for costeffective gene cloning. Commercial suppliers make it possible to obtain the synthetic DNA with codon optimization in just a few weeks. In this study, DNA of the rice genes OsNAR2.1 and OsNRT2.3a were codon optimized and synthesized for oocyte expression. The cRNA of OsNAR2.1 and OsNRT2.3a were then synthesized using a commercially available kit. We compared how this process may improve the functional activity of plant nitrate transporter proteins expressed in oocytes. The nitrate transport activity was assayed using ${ }^{15} \mathrm{~N}$-enriched nitrate uptake and the two-electrode voltage clamp technique.

\section{Results and discussion}

\section{Codon optimization of OsNAR2.1 and OsNRT2.3a}

There are some general rules that emerge from the analysis of the preferred codons in Xenopus and these can be used to optimize a gene sequence for expression in oocytes [30]. Using the codon usage bias software for Xenopus (http://www.kazusa.or.jp/codon/; http://genomes. urv.es/OPTIMIZER/), the DNA gene sequence was optimized for OsNAR2.1 (LOC_Os02g38230) and OsNRT2.3a (LOC_Os01g50820) and the resulting DNA sequences were synthesized by the Genescript Company and named syn-OsNAR2.1 and syn-OsNRT2.3a. After software optimization, the predicted GC content of syn-OsNAR2.1 and syn-OsNRT2.3a was adjusted from 72.0 to $52.6 \%$ and 67.2 to $49.0 \%$ respectively, when compared with the original genes (Table 1). This change now makes the plant genes synthetic DNA much closer to the typical $50 \%$ GC content found in Xenopus [31]. For both synthetic DNAs the melting temperature $\left(\mathrm{T}_{\mathrm{m}}\right)$ was decreased and the number of repeat sequences was decreased in syn-OsNAR2.1 (see Table 1). Sequence alignment of the open reading frames showed that syn-OsNAR2.1 and syn-OsNRT2.3a shared $73 \%$ and $74 \%$ identity with the original genes (Figure 1), but the amino acid sequences did not change after optimization (see Additional file 1).

\section{Nitrate uptake of oocytes}

The original and synthetic (optimized) OsNAR2.1 and OsNRT2.3a were subcloned in to expression vector pT7Ts [30] and then used as template to synthesize mRNA. Mixed mRNA of either synthetic genes (syn-OsNAR2.1: syn-OsNRT2.3a) or the original genes (ori-OsNAR2.1: oriOsNRT2.3a) were injected into oocytes. Both RNA mixes were injected at the same ratio (OsNAR2.1:OsNRT2.3a, 25:50 ng). We used a colorimetric method to assay the amount of nitrate accumulated inside the oocyte. After $16 \mathrm{~h}$ incubation in MBS containing $0.5 \mathrm{mM} \mathrm{NaNO}_{3}$, oocytes injected with mRNA of synthetic genes showed increased $\mathrm{NO}_{3}^{-}$uptake when compared with the original genes (Figure 2). Similar results were obtained in $5 \mathrm{mM}$ $\mathrm{NaNO}_{3}$ (Additional file 2). These data did not show a significant difference between the original genes and water injected oocytes. In another set of experiments, injected oocytes were incubated in MBS containing $0.5 \mathrm{mM}$ $\mathrm{Na}^{15} \mathrm{NO}_{3}^{-}$for 8 and $16 \mathrm{~h}$. Compared to original genes, ${ }^{15} \mathrm{NO}_{3}^{-}$uptake of single oocyte injected with synthetic genes were greatly enhanced after $8 \mathrm{~h}$ and $16 \mathrm{~h}$ incubation (Figure 3). Individual oocytes injected with synthetic gene mRNAs generally showed much greater ${ }^{15} \mathrm{NO}_{3}^{-}$uptake

Table 1 DNA sequence parameters of optimized plant transporter genes OsNAR2.1 and OsNRT2.3a

\begin{tabular}{|c|c|c|c|c|c|c|}
\hline & & & \multicolumn{2}{|c|}{ OsNAR2.1 } & \multicolumn{2}{|c|}{ OsNRT2.3a } \\
\hline & & & Synthetic & Original & Synthetic & Original \\
\hline \multicolumn{3}{|l|}{ GC content (\%) } & 52.6 & 71.0 & 49.0 & 67.2 \\
\hline & Max direct repeat & Size: & 8 & 11 & 10 & 13 \\
\hline & & Distance: & 7 & 177 & 984 & 993 \\
\hline & & Frequency: & 2 & 2 & 2 & 2 \\
\hline & Max inverted repeat & Size: & 10 & 11 & 12 & 11 \\
\hline \multirow[t]{5}{*}{ Repeat sequence } & & $\mathrm{Tm}$ & 27.3 & 55.7 & 48.8 & 53.6 \\
\hline & & Start positions & 3,475 & 165,54 & 230,1497 & 764,615 \\
\hline & Max dyad repeat & size & 9 & 11 & 10 & 11 \\
\hline & & $\mathrm{Tm}$ & 27.5 & 59.8 & 31.9 & 50.2 \\
\hline & & Start positions & 151,450 & $363,540,73$ & 198,1156 & 309,1442 \\
\hline \multirow[t]{2}{*}{ Cis-acting element } & PolyT & & 0 & 0 & 0 & 0 \\
\hline & PolyA & & 0 & 0 & 0 & 0 \\
\hline
\end{tabular}




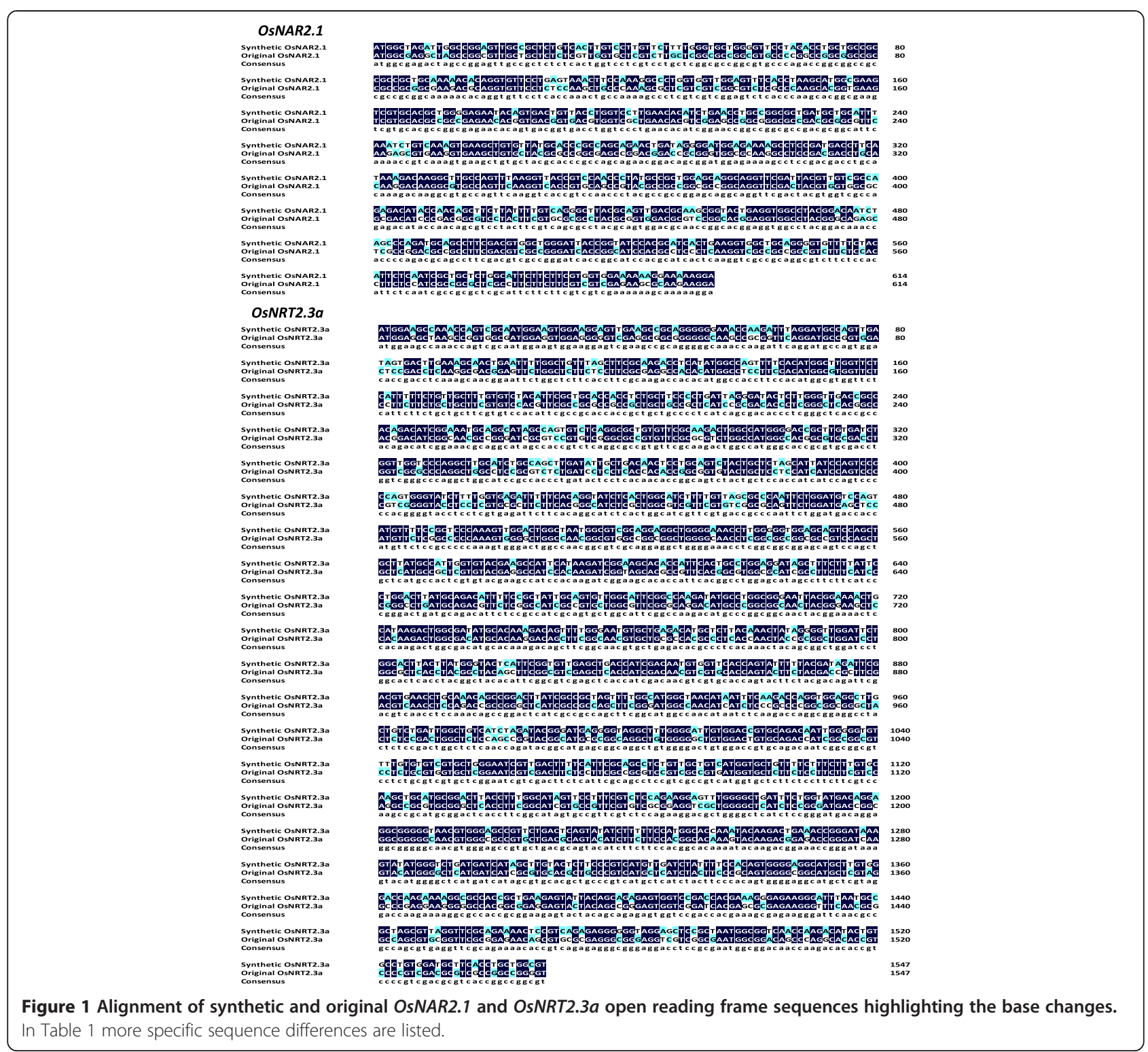

after $8 \mathrm{~h}$ and $16 \mathrm{~h}$ when compared with oocytes injected with RNA made using the original plant DNA template (Figure 4A, B). The longer incubation time resulted in more nitrate accumulation also perhaps a greater concentration of transporter protein in the membrane has developed after $16 \mathrm{~h}$. Statistical analysis showed that 100\% of oocytes injected with synthetic DNA had significantly increased ${ }^{15} \mathrm{NO}_{3}{ }^{-}$uptake after $8 \mathrm{~h}$ and $16 \mathrm{~h}$, while the equivalent figure was only $14 \%$ and $17 \%$ for the original plant template relative to water-injected controls (Figure 4). Presumably, the low percentage of nitrate transporter activity in oocytes injected with RNA from the plant DNA template can explain the results shown in Figure 2, where there was no significant difference between the total nitrate uptake of original genes-injected oocytes and waterinjected ones in an $8 \mathrm{~h}$ uptake experiment.

\section{Electrophysiological analyses of oocytes}

Two-electrode voltage clamp analysis was performed to record the voltage-current relationships of oocytes injected with mRNA [2,3]. After $48 \mathrm{~h}$ mRNA injected oocytes were treated with $0.5 \mathrm{mM} \mathrm{NaNO}_{3}$. Under these conditions when the plasma membrane voltage was clamped, in this example the nitrate-elicited currents of an oocyte injected with the synthetic genes was twice as large as an oocyte injected with RNA produced from the original plant DNA template (Figure 5). The electrophysiological measurements confirmed the accumulated nitrate (Figure 2) and ${ }^{15} \mathrm{~N}$-nitrate influx (Figure 3) data in showing larger nitrate-elicited currents in oocytes injected with RNA made using the synthetic optimized DNA template. The ${ }^{15} \mathrm{~N}$ influx data was the average of 20-25 oocytes and showed an 8-fold advantage of using 


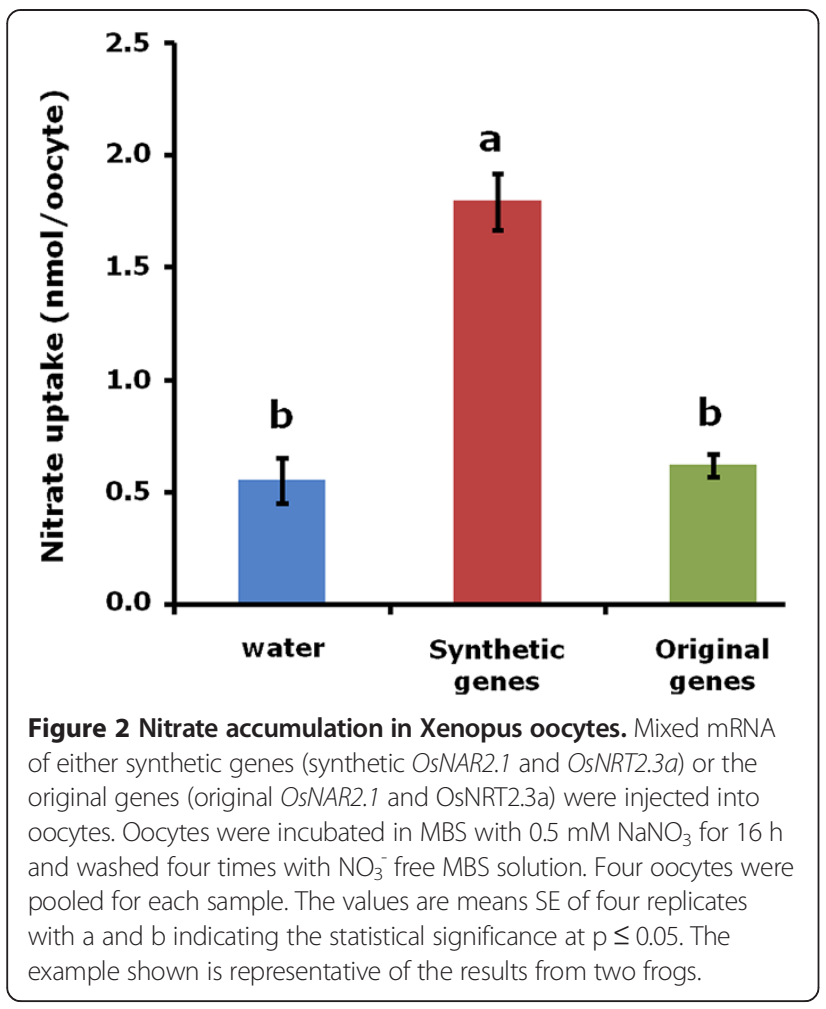

the optimized DNA. These data demonstrate the significant methodological advantage of using a template DNA that has been optimized for Xenopus expression.

\section{Enhanced transporter activity in oocytes}

The expression of foreign proteins in oocytes has long been known to be improved by the inclusion of a polyA tail and the use of expression vectors that include Xenopus

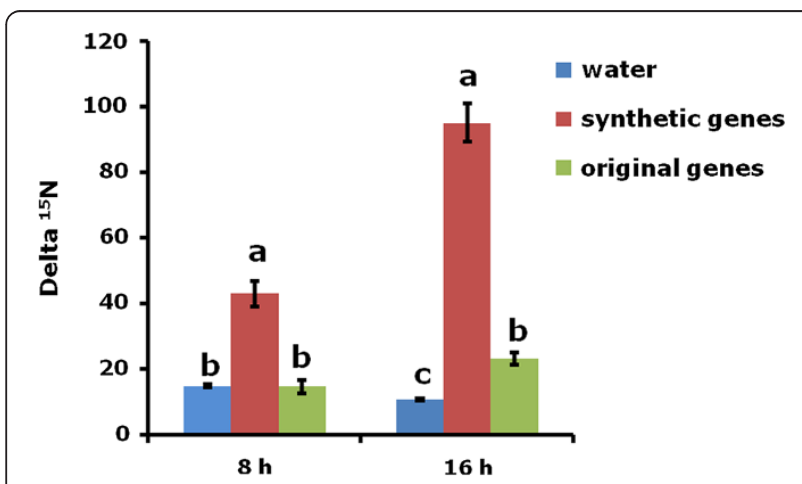

Figure $3{ }^{15} \mathrm{NO}_{3}^{-}$uptake in Xenopus oocytes. Mixed mRNA of either synthetic genes (synthetic OsNAR2.1 and OsNRT2.3a) or the original genes (original OsNAR2.1 and OsNRT2.3a) were injected into oocytes. Single oocyte was incubated in MBS with $0.5 \mathrm{mM} \mathrm{Na}^{15} \mathrm{NO}_{3}$ for $8 \mathrm{~h}$ and $16 \mathrm{~h}$, and then washed four times with cold $0.5 \mathrm{mM} \mathrm{NaNO}_{3}$ before ${ }^{15} \mathrm{~N}$ analysis. Data are averaged and SE of five oocytes. $a, b$ and $c$ indicate the significant difference at $p \leq 0.05$ of same template DNA between different treatments at $5 \%$ of probability. The example shown is representative of the results from two frogs.

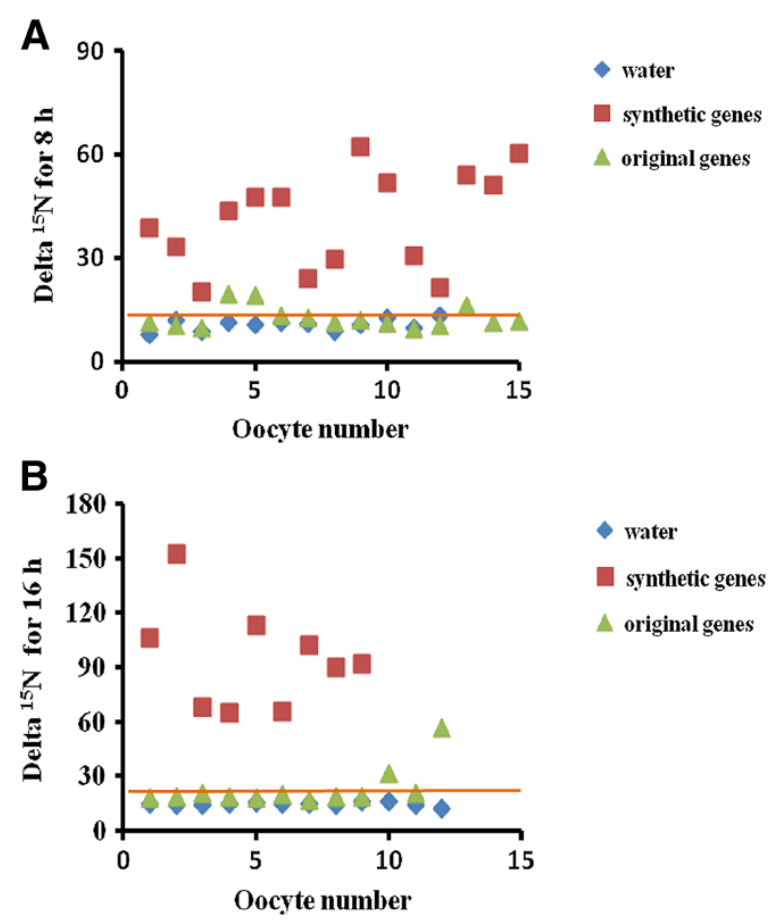

Figure 4 Data spread analysis of ${ }^{15} \mathrm{~N}$-nitrate influx for individual oocytes injected with water or RNA. Injected oocytes were incubated in MBS solution containing $0.5 \mathrm{mM} \mathrm{Na}^{15} \mathrm{NO}_{3}$ for 8 and $16 \mathrm{~h}$. Delta ${ }^{15} \mathrm{~N}$ influx of individual oocytes injected with water (blue), RNA prepared from synthetic template DNA (red) and original genes (green) were compared. The data are from 10-15 cells after $8 \mathrm{~h}$ (A) or $16 \mathrm{~h}$ (B) incubation. The line (orange) represents the expected ${ }^{15} \mathrm{~N}$ influx value for an oocyte injected with the original plant DNAtemplate RNA. At both $8 \mathrm{~h}(\mathbf{A})$ and $16 \mathrm{~h}$ (B), 100\% of the synthetictemplate RNA injected oocytes were above this threshold line, while the equivalent figure for the original plant DNA were 14 and $17 \%$ at 8 and $16 \mathrm{~h}$ respectively.

globin flanking UTR (untranslated region) sequence alongside the foreign DNA $[1,29,30]$. The polyA tail is recognized to improve mRNA stability and lifetime in the oocyte thereby improving the production of a foreign protein. The frog globin flanking UTR sequence is thought to make the heterologous cDNA more Xenopus-like and therefore thought to improve translation [29,30]. Similarly the mRNA produced from the synthetic DNA is more like Xenopus message and this has resulted in improved translational efficiency in the oocyte. For OsNAR2.1 the removal of some repeat sequence (Table 1) may also have given better translation of the foreign protein. Making the GC content more like the $50 \%$ found in Xenopus [31] is likely to improve expression of plant genes. In Arabidopsis the GC content was reported as $44 \%$, on the other hand in maize, rice and barley the figure was higher at $>60 \%$ [32]. Mammals usually have around $44 \% \mathrm{GC}$ in their coding sequence and experimental work directly comparing low-GC genes with their high-GC counterparts showed 100-fold greater expression in the GC-rich genes [33]. This study also 


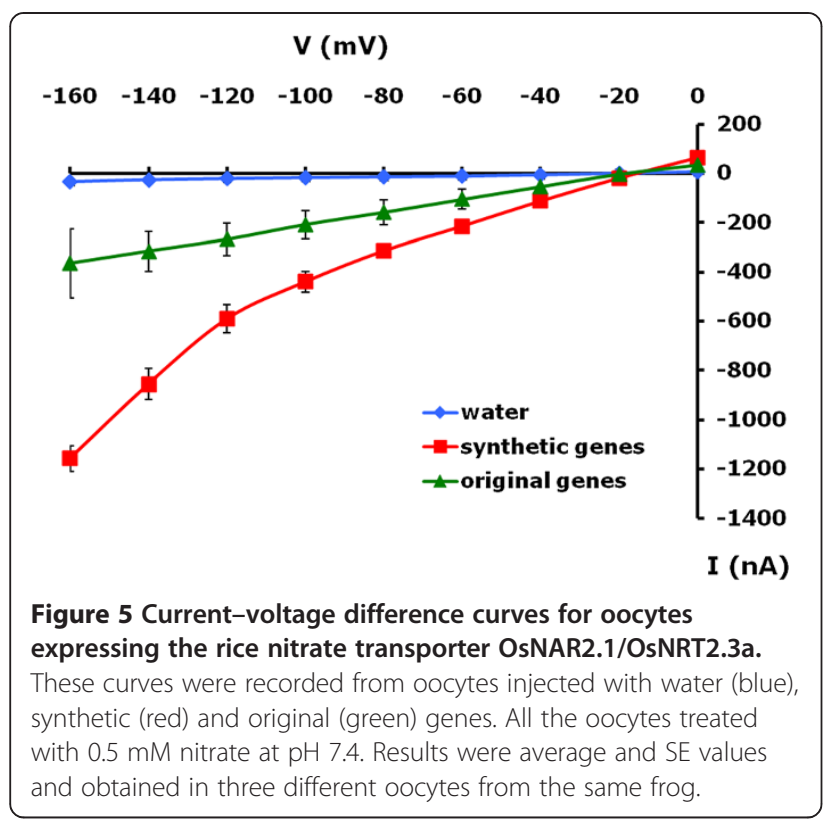

showed that the mRNA degradation rate was independent of the GC content.

Together these data clearly show the methodological advantage for plant genes of using a synthetic template that has codon usage more like that found in Xenopus. It is widely accepted that optimized codons help to achieve faster translation rates and high accuracy in bacteria, yeast and mammalian cells [24-28,34] and we now show this has advantages for plant genes in Xenopus oocytes too.

\section{Conclusion}

In this study, rice nitrate transporter OsNAR2.1 and OsNRT2.3a were codon optimized for Xenopus laevis. Nitrate transport activity was analyzed and compared between oocytes injected with different sources of template DNA. The optimization changes the DNA, but not the protein sequence. Compared with the original plant genes, oocytes injected with optimized genes had increased nitrate uptake and larger currents in electrophysiological analyses suggesting that there was an increased level of protein expression. Taken together, these data show that the codon optimized template can give much improved expression and therefore provides a big advantage when aiming to functionally characterize a plant transporter protein in the Xenopus oocyte system. Although this may not be the case for all plant transporter genes the relatively cheap cost of DNA synthesis now makes this worthwhile when using oocyte expression.

\section{Methods}

Cloning and mRNA synthesis of OsNAR2.1 and OsNRT2.3a OsNAR2.1 and OsNRT2.3a were codon optimized and synthesized by the Genescript Company. cDNAs were then subcloned into the BglII and SpeI sites of the oocyte expression vector pT7TS [35] using a directional cloning method. Original OsNAR2.1 and OsNRT2.3a construct are as described previously [22]. Plasmid was linearized by BamH I (Roche) and purified by PCR purification kit (QIAGEN). The mRNA synthesis kit (mMESSAGE mMA$\mathrm{CHINE}^{\ominus}$ T7 Kit, Ambion) was used to synthesized the mRNA of all genes. A compressed air system (Harvard) was used for injection [1]. Glass tips were calibrated for injection using known volumes and $1 \mu \mathrm{l}$ mRNA mixtures $(0.5 \mu \mathrm{g}$ OsNAR2.1 and $1 \mu \mathrm{g}$ OsNRT2.3a in total $)$ were used to inject around $22-25$ oocytes. Thus mRNA mixtures were injected as $25 \mathrm{ng}$ : $50 \mathrm{ng}$, OsNAR2.1: OsNRT2.3a, and this weight ratio was chosen to reflect the differing molecular sizes and give similar molecular ratios $[22,23]$. Oocytes from three different frogs were used for the data shown.

\section{$\mathrm{NO}_{3}^{-}$accumulation and ${ }^{15} \mathrm{~N}-\mathrm{NO}_{3}^{-}$uptake in oocytes}

After injection, the oocytes were incubated for 2 days in $\mathrm{NO}_{3}{ }^{-}$free MBS solution $(88 \mathrm{mM} \mathrm{NaCl}, 1 \mathrm{mM} \mathrm{KCl}$, $2.4 \mathrm{mM} \mathrm{NaHCO} 3,0.71 \mathrm{mM} \mathrm{CaCl}, 0.82 \mathrm{mM} \mathrm{MgSO}_{4}$ and $15 \mathrm{mM}$ HEPES, $\mathrm{pH}$ 7.4). The solution contains $10 \mathrm{~g} / \mathrm{ml}$ sodium penicillin and $10 \mathrm{~g} / \mathrm{ml}$ streptomycin sulphate. For $\mathrm{NO}_{3}^{-}$measurement, oocytes were incubated in MBS solution containing $0.5 \mathrm{mM} \mathrm{NaNO}_{3}$ at $18^{\circ} \mathrm{C}$ for $16 \mathrm{~h}$. After incubation, oocytes were washed with $\mathrm{NO}_{3}{ }^{-}$free MBS for four times. Four oocytes were collected as one sample in $1.5 \mathrm{~mL}$ tube, and $100 \mu \mathrm{l} \mathrm{H} \mathrm{H}_{2} \mathrm{O}$ was added into the tube. Lyses the oocytes and centrifuge the tube at $13000 \mathrm{rpm}$. The supernatants $(40 \mu \mathrm{l})$ were collected for $\mathrm{NO}_{3}{ }^{-}$assay using the kit (Nitrate/Nitrite Colorimetric Assay kit, Cayman).

For ${ }^{15} \mathrm{~N}-\mathrm{NO}_{3}{ }^{-}$measurement, oocytes were incubated in MBS solution containing $0.5 \mathrm{mM} \mathrm{Na}{ }^{15} \mathrm{NO}_{3}$ with a $99 \%$ atom excess of ${ }^{15} \mathrm{~N}$ for $8 \mathrm{~h}$ and $16 \mathrm{~h}$. oocytes were washed four times with ice-cold $0.5 \mathrm{mM} \mathrm{NaNO}_{3} \mathrm{MBS}$. Single oocyte was transferred to an empty tin capsule and then dried at $60^{\circ} \mathrm{C}$ for one week. Analysis for total ${ }^{15} \mathrm{~N}$ content using a continuous-flow isotope ratio mass spectrometer coupled with a carbon nitrogen elemental analyzer (ANCA-GSLMS; PDZ Europa). The delta- ${ }^{15} \mathrm{~N}$ was calculated as described previously [4].

\section{Two-electrode voltage clamp analysis}

The nitrate-elicited currents were recorded in oocyte using two-electrode voltage clamp method (pClamp 10.2, Axon). The oocytes were incubated in nitrate-free MBS and then treated with MBS containing $0.5 \mathrm{mM}$ sodium nitrate. Membrane potential of oocytes was pulsed from 0 to $-160 \mathrm{mV}$ with $20 \mathrm{mV}$ incremental steps. The currents were recorded to obtain current-voltage curves [2-4]. 


\section{Additional files}

Additional file 1: Figure S1. Alignment of synthetic and original OsNAR2.1 and OsNRT2.3a amino acid sequences showing they encoded identical proteins.

Additional file 2: Nitrate accumulation in Xenopus oocytes in different concentration of nitrate. Oocytes were incubated in MBS with $0.5 \mathrm{mM}$ and $5 \mathrm{mM} \mathrm{NaNO}_{3}$ for $16 \mathrm{~h}$ and washed four times with $\mathrm{NO}_{3}{ }^{-}$free MBS solution. Four oocytes were pooled for each sample. The values are means SE of four replicates with $a$ and $b$ indicating the statistical significance at $p \leq 0.05$

\section{Competing interests}

The authors declare that they have no competing interests.

\section{Authors' contributions}

AJM and XF conceived the study. HF, XX and XF carried out the experiments. $\mathrm{HF}$ drafted the manuscript and all authors approved the final version.

\section{Acknowledgements}

This work was funded by the China 973 Program (grant number 2011CB100300), the National Natural Science Foundation, the PAPD and 111 Project (grant number 12009). AJM is supported by grant funding BB/JJ004553/ 1 from the BBSRC and the John Innes Foundation. The oocytes used in this work were kindly donated by the Gurdon Institute, Cambridge, UK.

Received: 2 October 2013 Accepted: 13 December 2013

Published: 20 December 2013

\section{References}

1. Boorer KJ, Forde BG, Leigh RA, Miller AJ: Functional expression of a plant plasma membrane transporter in Xenopus oocytes. FEBS Lett 1992, 302:166-168.

2. Cao YW, Anderova M, Crawford NM, Schroeder Jl: Expression of an outward-rectifying potassium channel from maize mRNA and complementary RNA in Xenopus oocytes. Plant Cell 1992, 4:961-969.

3. Zhou JJ, Theodoulou FL, Muldin I, Ingemarsson B, Miller AJ: Cloning and functional characterization of a Brassica napus transporter which is able to transport nitrate and histidine. J Biol Chem 1998, 273:12017-12023.

4. Tong YP, Zhou JJ, Li ZS, Miller AJ: A two-component high-affinity nitrate uptake system in barley. Plant J 2005, 10:1365-1374.

5. Kotur Z, Mackenzie N, Ramesh S, Tyerman SD, Kaiser BN, Glass AD: Nitrate transport capacity of the Arabidopsis thaliana NRT2 family members and their interactions with AtNAR2.1. New Phytol 2012, 194:724-731.

6. Schachtman DP, Schroeder JI, Lucas WJ, Anderson JA, Gaber RF: Expression of an inward-rectifying potassium channel by the Arabidopsis KAT1 Cdna. Science 1992, 258:1654-1658.

7. Chilcott TC, Shartzer SF, Iverson MW, Garvin DF, Kochian LV, Lucas WJ: Potassium transport kinetics of KAT1 expressed in Xenopus oocytes: a proposed molecular structure and field effect mechanism for membrane transport. CR Acad Sci Paris 1995, 318:761-771.

8. Véry A, Gaymard F, Bosseux C, Sentenac H, Thibaud J: Expression analysis of a cloned plant $\mathrm{K}^{+}$channel in Xenopus oocytes analysis of macroscopic currents. Plant J 1995, 7:321-332.

9. Wang $Y$, Wu WH: Potassium transport and signaling in higher plants. Annu Rev of Plant Biol 2013, 64:451-476.

10. Daniels MJ, Mirkov TE, Chrispeels MJ: The plasma membrane of Arabidopsis thaliana contains a mercury insensitive aquaporin that is a homolog of the tonoplast water channel protein TIP. Plant Physiol 1994, 106:1325-1333.

11. Johansson I, Karlsson M, Shukla VK, Chrispeels MJ, Larsson C, Kjellbom P: Water transport activity of the plasma membrane aquaporin PM28A is regulated by phosphorylation. Plant Cell 1998, 10:451-459

12. Higuchi T, Suga S, Tsuchiya T, Hisada H, Morishima S, Okada Y, Maeshim M a, Molecular cloning, water channel activity and tissue speciçc expression of two isoforms of the radish vacuolar aquaporin. Plant Cell Physiol 1998, 39:905-913.

13. Hu W, Yuan QQ, Wang Y, Cai R, Deng XM, Wang J, Zhou SY, Chen LH, Huang C, Ma ZB, Yang GX, He GY: Overexpression of a wheat aquaporin gene, $T a A Q P 8$, enhances salt stress tolerance in transgenic tobacco. Plant and Cell Physiol 2012, 53:2127-2141.
14. Liu KH, Huang CY, Tsay YF: CHL1 is a dual-affinity nitrate transporter of Arabidopsis involved in multiple phases of nitrate uptake. Plant Cell 1999, 11:865-874

15. Lin CM, Koh S, Stacey G, Yu SM, Lin TY, Tsay YF: Cloning and functional characterization of a constitutively expressed nitrate transporter gene, OsNRT1, from rice. Plant Physiol 2000, 122:379-388.

16. Chiu CC, Lin CS, Hsia AP, Su RC, Lin HL, Tsay YF: Mutation of a nitrate transporter, AtNRT1;4, results in a reduced petiole nitrate content and altered leaf development. Plant Cell Physiol 2004, 45:1139-1148.

17. Almagro A, Lin SH, Tsay YF: Characterization of the arabidopsis nitrate transporter NRT1.6 reveals a role of nitrate in early embryo development. Plant Cell 2008, 20:3289-3299.

18. Fan SC, Lin CS, Hsu PK, Lin SH, Tsay YF: The Arabidopsis nitrate transporter NRT1.7, expressed in phloem, is responsible for source-to-sink remobilization of nitrate. Plant Cell 2009, 21:2750-2761.

19. Li JY, Fu YL, Pike SM, Bao J, Tian W, Zhang Y, Li HM, Huang J, Li LG, Schroeder JI, Gassmann W, Gong JM: The Arabidopsis nitrate transporter NRT1.8 functions in nitrate removal from the xylem sap and mediates cadmium tolerance. Plant Cell 2010, 22:1633-1646.

20. Wang YY, Tsay YF: Arabidopsis nitrate transporter NRT1.9 is important in phloem nitrate transport. Plant Cell 2011, 23:1945-1957.

21. Zhou JJ, Fernandez E, Galvan A, Miller AJ: A high affinity nitrate transport system from Chlamydomonas requires two gene products. FEBS Lett 2000, 466:225-227.

22. Feng HM, Yan M, Fan XR, Li BZ, Shen QR, Miller AJ, Xu GH: Spatial expression and regulation of rice high-affinity nitrate transporters by nitrogen and carbon status. J Exp Bot 2011, 62:2319-2332.

23. Yan M, Fan XR, Feng HM, Miller AJ, Sheng QR, Xu GH: Rice OsNAR2.1 interacts with OsNRT2.1, OsNRT2.2 and OsNRT2.3a nitrate transporters to provide uptake over high and low concentration ranges. Plant Cell Environ 2011, 34:1360-1372.

24. Burgess-Brown NA, Sharma S, Sobott F, Loenarz C, Oppermann U, Gileadi O: Codon optimization can improve expression of human genes in Escherichia coli: A multi-gene study. Protein Expr Purif 2008, 59:94-102.

25. Maertens B, Spriestersbach A, von Groll U, Roth U, Kubicek J, Gerrits M, Graf M, Liss M, Daubert D, Wagner R, Schäfer F: Gene optimization mechanisms: a multi-gene study reveals a high success rate of full-length human proteins expressed in Escherichia coli. Protein Sci 2010, 19:1312-1326.

26. Tu YB, Wang YQ, Wang G, Wu J, Liu YG, Wang SJ, Jiang CG, Cai XH: Highlevel expression and immunogenicity of a porcine circovirus type 2 capsid protein through codon optimization in Pichia pastoris. Appl Microbio and Biotechnol 2013, 97:2867-2875.

27. Wurm FM: Production of recombinant protein therapeutics in cultivated mammalian cells. Nat Biotechnol 2004, 22:1393-1398.

28. Fath S, Bauer A, Liss M, Spriestersbach A, Maertens B, Hahn P, Ludwig C, Schäfer F, Graf M, Wagner R: Multiparameter RNA and codon optimization: a standardized tool to assess and enhance autologous mammalian gene expression. PloS One 2011, 6:e17596.

29. Miller AJ, Zhou J-J: Xenopus oocytes as an expression system for plant transporters. Biochim Biophys Acta 2000, 1465:343-358.

30. Musto H, Cruveiller S, D'Onofrio G, Romero H, Bernardi G: Translational selection on codon usage in Xenopus laevis. Mol Biol Evol 2001, 18:1703-1707.

31. Amin NM, Tandon P, Osborne Nishimura E, Conlon FL: RNA-seq in the tetraploid Xenopus laevis enables genome-wide insight in a classic developmental biology model organism. Methods 2013. (in press) http://dx.doi.org/10.1016/j.ymeth.2013.06.009.

32. Carels N, Bernardi G: Two classes of genes in plants. Genetics 2000, 154:1819-1825.

33. Kudla G, Lipinski L, Caffin F, Helwak A, Zylicz M: High guanine and cytosine content increases mRNA levels in mammalian cells. PLOS Biology 2006, 4(e180):0933-0942

34. Gustafsson C, Govindarajan S, Minshull J: Codon bias and heterologous protein expression. Trends Biotechnol 2004, 22:346-353.

35. Cleaver $\mathrm{O}$, Patterson KD, Krieg PA: Overexpression of the tinman-related genes XNkx-2.5 and XNkx-2.3 in Xenopus embryos results in myocardial hyperplasia. Development 1996, 122:3549-3556.

doi:10.1186/1746-4811-9-48

Cite this article as: Feng et al: Optimizing plant transporter expression in Xenopus oocytes. Plant Methods 2013 9:48. 